\title{
?12 tinbergen
}

TI 2019-088/V

Tinbergen Institute Discussion Paper

\section{More bottle banks only imply a small increase in recycling of glass in the Netherlands}

Elbert Dijkgraaf ${ }^{1}$

Raymond Gradus ${ }^{2}$

${ }^{1}$ Erasmus University Rotterdam

2 Vrije Universiteit Amsterdam 
Tinbergen Institute is the graduate school and research institute in economics of Erasmus University Rotterdam, the University of Amsterdam and VU University Amsterdam.

Contact: discussionpapers@tinbergen.nl

More TI discussion papers can be downloaded at https://www.tinbergen.nl

Tinbergen Institute has two locations:

Tinbergen Institute Amsterdam

Gustav Mahlerplein 117

1082 MS Amsterdam

The Netherlands

Tel.: +31(0)205984580

Tinbergen Institute Rotterdam

Burg. Oudlaan 50

3062 PA Rotterdam

The Netherlands

Tel.: +31(0)10408 8900 


\title{
More bottle banks only imply a small increase in recycling of glass in the Netherlands Elbert Dijkgraaf ${ }^{1}$ and Raymond Gradus ${ }^{2}$
}

\begin{abstract}
The Netherlands advocates a glass recycling rate of more than 90\%. In 2017, the rate is $86 \%$. To reach this goal the Human Environment and Transport Inspectorate wants to improve the collection infrastructure by increasing the number of bottle banks with 800 by 2021. However, a cost-effectiveness analysis is lacking. Based on empirical evidence with data from 2007-2017, we show that increasing the number of bottle banks is rather ineffective. Implementing an unit-based pricing system can be more effective, although this can have serious drawbacks.
\end{abstract}

Keywords: Glass recycling, re-use target, waste infrastructure, local government, Netherlands

\section{Introduction}

Lack of space and a growing environmental awareness forced Dutch governments to take measures in the 1980s and 1990s to reduce the landfilling of unsorted (household) waste and to stimulate recycling and incineration of waste through energy recovery (Dijkgraaf and Gradus, 2017). Separate collection of glass, paper and compostable waste became obligatory. Later, these measures were intensified with a tax on landfilling and a landfill ban and separate collection of plastic. According to the EU, $60 \%$ of municipal waste should be recycled in 2030. The Dutch recycling rate is with $46 \%$ in 2016 above the EU average of $38 \%$ (see Eurostat, 2019). Nevertheless, the Netherlands increased the EU goal even further by demanding that $75 \%$ should be recycled in 2020 and that everyone should be allowed to have only 100 kilogram of unsorted waste per year in 2020 and only 30 kilograms in 2025 . To achieve this goal, separation and recycling of glass, paper/carton, plastic and textiles are crucial.

Most Dutch municipalities have an advanced infrastructure of curbside collection of unsorted waste and recyclables as compostable waste and plastics and easily assessable bring locations for glass bottles, paper and textiles (Dijkgraaf and Gradus, 2017). In addition, more and more

1 Erasmus School of Economics and Tinbergen Institute, Erasmus University Rotterdam, email: dijkgraaf@ese.eur.nl.

2 School of Business \& Economics and Tinbergen Institute, Vrije Universiteit Amsterdam, email: r.h.j.m.gradus@vu.nl; corresponding author. 
Dutch municipalities introduce unit-based pricing (UBP) systems for waste, as these unitbased pricing systems are effective in reducing unsorted waste and stimulating recycling. However, a drawback of unit-based pricing is illegal dumping, although data to verify this are not easily available. By 2017, 45 percent of all Dutch municipalities had implemented a unitbased pricing system. This share increased substantially from 16 percent in 1999 (Gradus and Dijkgraaf, 2019). This is different from the United States, where in 2015 only $10 \%$ of municipalities had unit-based pricing or pay-as-you-throw (Gradus et al., 2019).

For packaging materials as glass and plastics separate goals are available. For plastic, the EU target for re-use of plastic packaging is $55 \%$ by 2030 . The Netherlands recycled $52 \%$ in 2018 , only $3 \%$ below this goal. Home separation of plastic waste is quite expensive as it demands a separate collection infrastructure and storage and transport of low-density volumes (Gradus et al., 2017). In Gradus et al. (2017) we calculate the implicit price of 1 metric ton of $\mathrm{CO}_{2}$ reduction by means of plastic home separation and recycling (compared with incineration) and show that it is equal to 178 euro. In general, this implicit price is much higher than current (or historic) ETS prices, the estimated external costs of $\mathrm{CO}_{2}$ emissions, or alternatives to reduce $\mathrm{CO}_{2}$ emissions (e.g. solar or wind-energy). Therefore, the Packaging Waste Fund stimulates post separation of plastic waste as this results in a larger quantity per household and there are indications that it is cheaper and the quality is higher (Dijkgraaf and Gradus, 2016).

For glass, the focus of this paper, the European Union advocates a recycling rate of $75 \%$. In 2017, the Netherlands recycled $86 \%$ of their glass, far above the EU-goal. Nevertheless, the Netherlands has set an even higher goal by demanding that $90 \%$ should be recycled in 2021 and the Human Environment and Transport Inspectorate (ILT) has forced the Packaging Waste Fund to reach this goal by increasing the number of bottle banks. However, a cost effectiveness analysis is lacking, and this paper tries to fill this gap by modelling the separate collection of glass waste per inhabitants as a function of the number of bottle banks. Similar to Dijkgraaf and Gradus (2017), we correct also for unit-based pricing, curbside frequency variables and socio-economic variables.

The paper is organized as follows. In Section 2, data and methods are discussed. Estimation results for the basic model are given in Section 3 and in Section 4 we give a robustness 
analysis. Furthermore, a cost effectiveness for increasing the number of bottle banks is given in section 5. Finally, Section 6 contains some conclusions and discussion.

\section{Data and methods}

Data for the socio-economic characteristics and the number of bottle banks come from CBS.

Data on unit-based pricing and the amount of glass waste in kilograms per inhabitant come from Netherlands Enterprise Agency. Total glass waste in the Netherlands is yearly approximately 22 kilograms (49 pounds) per inhabitant. We have data for 440 municipalities for the period 2007-2017, with a total of 3,647 observations. Also data for glass waste are available from the Packaging Waste Fund for 2010-2017 and we use these data in the robustness analysis as the fund claims that these data are more reliable. ${ }^{3}$ Furthermore, Statistics Netherlands (CBS) collects yearly information on the number of times in a year curbside collection of (unsorted) waste takes place. For descriptive statistics, see Table 1.

Table 1. Descriptive statistics

\begin{tabular}{|c|c|c|c|c|}
\hline & Average & Max. & Min. & Std. Dev. \\
\hline Glass in $\mathrm{kg}$ per inhabitant & 22.07 & 45.24 & 8.00 & 4.54 \\
\hline Glass in kg per inhabitant (data Packaging Fund) & 21.99 & 38.88 & 7.38 & 4.43 \\
\hline Bottle banks per 1000 inhabitants & 1.09 & 4.85 & 0.18 & 0.45 \\
\hline Bottle banks per municipality & 41.81 & 1,228 & 3.00 & 64.71 \\
\hline Bottle banks per $\mathrm{km}^{2}$ & 0.73 & 6.77 & 0.02 & 0.90 \\
\hline UBP: volume (dummy) & 0.08 & 1.00 & 0.00 & 0.27 \\
\hline UBP: frequency (dummy) & 0.22 & 1.00 & 0.00 & 0.42 \\
\hline UBP: bag (dummy) & 0.05 & 1.00 & 0.00 & 0.22 \\
\hline UBP: weight (dummy) & 0.05 & 1.00 & 0.00 & 0.22 \\
\hline Population density (inhabitants per hectare) & 316 & 2912 & 13 & 402 \\
\hline Inhabitants & 41,474 & 821,752 & 4,266 & 60,417 \\
\hline Household size & 2.38 & 3.55 & 1.66 & 0.19 \\
\hline Income $(€)$ & 33.37 & 68.12 & 22.92 & 3.58 \\
\hline Elderly (\%) & 17.63 & 30.95 & 6.89 & 3.39 \\
\hline Ethnicity $(\%)$ & 5.67 & 37.91 & 0.73 & 5.13 \\
\hline Dummy: low frequency unsorted: 0-12 & 0.03 & 1.00 & 0.00 & 0.18 \\
\hline Dummy: low frequency unsorted: $13-17$ & 0.02 & 1.00 & 0.00 & 0.12 \\
\hline Dummy: few banks ( $<75 \%$ of average) & 0.15 & 1.00 & 0.00 & 0.28 \\
\hline Dummy: very few banks ( $<50 \%$ of average $)$ & 0.02 & 1.00 & 0.00 & 0.10 \\
\hline Dummy: many banks ( $>125 \%$ of average) & 0.35 & 1.00 & 0.00 & 0.72 \\
\hline Dummy: very many banks ( $>150 \%$ of average) & 0.17 & 1.00 & 0.00 & 0.60 \\
\hline Dummy: inhabitants $>100,000$ & 0.07 & 0.00 & 1.00 & 0.26 \\
\hline Dummy: inhabitants $>50,000$ & 0.18 & 0.00 & 1.00 & 0.38 \\
\hline Dummy: inhabitants $<10,000$ & 0.07 & 0.00 & 1.00 & 0.25 \\
\hline
\end{tabular}

\footnotetext{
${ }^{3}$ The correlation between the data from the CBS and the Packaging Waste Fund is very high (i.e. 0.96).
} 
We model the amount of (separate collected) glass per inhabitant as a function of the number of bottle banks (per 1,000 inhabitants), the unit-based pricing system and socio-economic variables such as the number of inhabitants, household size, population density, income, share of elderly people and ethnicity, as follows:

$G I_{i t}=\propto_{0}+\propto_{1} B B_{i t}+\sum \propto_{2 j} U B P_{j t}+\sum \propto_{3 j} S E_{j t}+\delta_{i}+\gamma_{t}+\varepsilon_{i t}$

where $\mathrm{GI}_{\mathrm{it}}$ is the (separated) glass amount in kilograms per inhabitant of municipality $i$ in year $\mathrm{t}, \mathrm{BB}_{\mathrm{it}}$ is the number of bottle banks (per 1,000 inhabitants) in municipality $\mathrm{i}$ in year $\mathrm{t}, \mathrm{UBP}_{\mathrm{j}}$ is a dummy with value 1 if municipalities choose an unit-based pricing system (with as different systems payment based on volume (i), frequency (ii), bags (iii) and weight (iv)) and SEj the different socio-economic variables (i.e. the population density (households per $\mathrm{km}^{2}$ ), the number of inhabitants $(/ 10,000)$ and its square, household size (inhabitants per household), the yearly average income per household $(€ / 1.000)$, the share of elderly people (above 65 years) and the ethnicity (defined as the share of non-western inhabitants). Moreover, $\boldsymbol{\delta}_{\boldsymbol{j}}$ are the municipal fixed effects, $\gamma_{\boldsymbol{t}}$ is the vector with year dummies and $\varepsilon_{\mathrm{it}}$ is the error term. All estimations are based on pooled ordinary least squares (OLS).

\section{Results of the basic model}

Table 2 shows the estimations for the basic model. From the estimations in Table 2, we can conclude that increasing the number of bottle banks has a significant but small effect on the amount of glass waste per inhabitant. In the Netherlands the total amount of bottle banks in 2017 is 16,500 and per 1000 inhabitants this is 1.05 bottle bank. So, if the number of bottle banks increases with 800 as requested by ILT the number of bottle banks per inhabitants increases with 0.05 . Therefore, the (separated) glass amount in kilograms per inhabitant will only increase with 0.0145 (i.e. $0.29 * 0.05$ ).

Unit-based pricing systems are more effective in stimulating the separation of glass. In particular, the bag-based system is effective in stimulating glass recycling. From Table 2 it follows that the increase in glass per 1000 inhabitants from having such a system is 3.84 kilograms. Compared with the average quantity of glass in 2017 (21.82 kg per inhabitant) this 
is an increase of $18 \%$. If a frequency-based system or a weight-based system is chosen than the increase is respectively 2.5 and 2.2 kilograms extra, which in percentage is an increase of $11 \%$ and $10 \%$. However, these systems can have some adverse effects such as administrative costs and illegal or illicit dumping. In particular, the bag-based system is effective in increasing separate collection of glass, but it has additional adverse effects as labour laws limit the number of bags allowed to carry per day per worker.

\section{Table 2. Estimation basic model}

\begin{tabular}{lrl}
\hline & Basis & \\
\hline Bottle banks per 1000 inhabitants & 0.29 & $(0.14)^{* *}$ \\
UBP: volume & 0.42 & $(0.31)$ \\
UBP: frequency & 2.51 & $(0.24)^{* * *}$ \\
UBP: bag & 3.84 & $(0.55)^{* * *}$ \\
UBP: weight & 2.20 & $(0.59)^{* * *}$ \\
Population density & -0.002 & $(0.001)$ \\
Inhabitants/10000 & -0.01 & $(0.27)$ \\
(Inhabitants/10000) & \\
Household size & -0.001 & $(0.003)$ \\
Income $(€)$ & -0.52 & $(1.67)$ \\
Elderly $(\%)$ & 3.56 & $(44.49)$ \\
Ethnicity $(\%)$ & 0.15 & $(0.08)^{*}$ \\
Constant & -0.35 & $(0.10)^{* * *}$ \\
& 22.01 & $(4.64)^{* * *}$ \\
$\mathrm{R}^{2}$ & & \\
Observations & 0.81 & \\
\hline Notes: $* * / * *$ means significance at respectively $90 \% / 95 \% / 99 \%$ and standard \\
errors between brackets. & 3,647 & \\
& &
\end{tabular}

Let us focus on the other variables. First, the constant has a high explanatory power, which implies separating glass under citizens is already at a high level in the Netherlands, independent of the number of bottle banks and incentive structures as UBP. In terms of the socio-economic variables, we find that the share of elderly people (at 10\% level) and ethnicity are significant. Based on our results, non-western ethnic groups recycle less glass. If a municipality has $10 \%$-point more non-western people there is 3.5 kilograms less glass waste or $16 \%$ less recycling of glass. This is line with Abbott et al. (2013), who found that western 
ethnic groups have a stronger social norm to recycle. If a municipality has 10\%-point more elderly people than there is 1.5 kilogram more glass waste or $7 \%$ more recycling of glass.

\section{Robustness analysis}

In the robustness check, we firstly replace the number of bottle banks per inhabitant by the number per $\mathrm{km}^{2}$. Second, we also include a non-linear effect for the number of bottle banks per inhabitant. Third, we include a dummy if a municipality has a low frequency of collecting unsorted waste.

Table 3 Estimation alternatives: banks per $\mathbf{k m}^{2}$, non-linear and low frequency unsorted

\begin{tabular}{lccc} 
& Bottle banks per km & Non-linear & Low frequency unsorted \\
\hline Bottle banks per inhabitant & - & 0.53 & 0.22 \\
(Bottle banks per inhabitant) $^{2}$ & - & -0.07 & - \\
Bottle banks per km ${ }^{2}$ & 0.27 & - & - \\
UBP: volume & 0.45 & 0.43 & 0.43 \\
UBP: frequency & $2.54^{* * *}$ & $2.52^{* * *}$ & $2.50^{* * *}$ \\
UBP: bag & $3.86^{* * *}$ & $3.85^{* * *}$ & $3.68^{* * *}$ \\
UBP: weight & $2.28^{* * *}$ & $2.23^{* * *}$ & $2.29^{* * *}$ \\
Dummy: low frequency unsorted: $0-12$ & - & - & $0.73^{* * *}$ \\
Dummy: low frequency unsorted: $13-17$ & - & - & 0.43 \\
Population density & -0.002 & -0.002 & $-0.003^{*}$ \\
Inhabitants/10000 & 0.01 & -0.02 & -0.13 \\
(Inhabitants/10000) & -0.001 & -0.001 & 0.002 \\
Household size & -0.55 & -0.57 & -0.04 \\
Income $(€)$ & 0.00 & 0.01 & 0.02 \\
Elderly $(\%)$ & $0.15^{*}$ & $0.14^{*}$ & $0.17^{* *}$ \\
Ethnicity $(\%)$ & $-0.36^{* * *}$ & $-0.35^{* * *}$ & $-0.31^{* * *}$ \\
Constant & $22.28^{* * *}$ & $21.98^{* * *}$ & $20.53^{* * *}$ \\
& & & \\
$\mathrm{R}^{2}$ & 0.81 & 0.81 & 0.81 \\
Observations & 3,647 & 3,647 & 3,262 \\
\hline
\end{tabular}

Note: $* * * / * * *$ means significance at respectively $90 \% / 95 \% / 99 \%$.

First, if we include bottle banks per $\mathrm{km}^{2}$ instead of per 1000 inhabitants, we do not even get significant result for bottle banks. We find the same result for the second estimation with nonlinear effect for bottle banks. Furthermore, some Dutch municipalities decreases the frequency of collecting unsorted waste and hereby want to increase separation of recyclables as glass. This is tested in the third estimations by including a dummy that is one if unsorted waste is collected 12 or less times a year and a dummy that is one if unsorted waste is collected between 13 and 17 times a year. Interestingly, for decreasing the frequency to 
twelve or less, we get a significant increase of glass with 3\%. This is still substantially less than introducing an unit-based pricing system. Again, the result for bottle banks is no longer significant. It should be noted that the results for unit-based pricing system and for ethnicity and elderly in these robustness analyses are similar to the results in the basic model. To sum up, the results for the bottle banks is not robust with respect to significance. In all three specifications the coefficient is no longer significant.

Table 4. Estimations three other alternatives

\begin{tabular}{lccc}
\hline & Data Packaging Fund & Few/Many & Very few/many \\
\hline Bottle banks per inhabitant & $0.26^{*}$ & 0.22 & 0.15 \\
Bottle banks per inh *Dummy: few banks & - & 0.32 & - \\
Bottle banks per inh *Dummy: very few banks & - & - & 0.01 \\
Bottle banks per inh *Dummy: many banks & - & 0.13 & - \\
Bottle banks per inh *Dummy: very many banks & - & - & 0.14 \\
UBP: volume & 0.47 & 0.38 & 0.42 \\
UBP: frequency & $2.51^{* * *}$ & $2.51^{* * *}$ & $2.50^{* * *}$ \\
UBP: bag & $3.83^{* * *}$ & $3.82^{* * *}$ & $3.84^{* * *}$ \\
UBP: weight & 0.65 & $2.19^{* * *}$ & $2.19^{* * *}$ \\
Population density & $-0.003^{* * *}$ & -0.002 & -0.002 \\
Inhabitants/10000 & $-0.83^{* * *}$ & -0.01 & -0.01 \\
(Inhabitants/10000) & $0.005^{* *}$ & -0.001 & -0.001 \\
Household size & -1.76 & -0.51 & -0.49 \\
Income $(€)$ & -0.05 & 0.00 & 0.00 \\
Elderly $(\%)$ & 0.01 & $0.15^{* *}$ & $0.15^{* *}$ \\
Ethnicity $(\%)$ & $-0.26^{* * *}$ & $-0.35^{* * *}$ & $-0.34 * * *$ \\
Constant & $32.25^{* * *}$ & $22.09^{* * *}$ & $22.10^{* * *}$ \\
$\mathrm{R}^{2}$ & & & \\
Observations & 0.88 & 0.81 & 0.81 \\
\hline Note: $* * * * *$ means significance at respectively $90 \% / 95 \% / 99 \%$ & 3647 & 3647 \\
\hline
\end{tabular}

In Table 4 three other alternatives are estimated. First, we include the glass data waste from the Packaging Waste Fund for 2010-2017. As these data are the basis for the fee the Packaging Waste Fund pays to municipalities and the fund claims that these data are more reliable, we use these data in a robustness analysis. Second, as the number of bottle banks per 1000 inhabitants varies heavily between 0.18 (minimum) and 4.85 (maximum) we test whether the effectiveness of increasing the number of bottle banks depend on the density of the existing collection infrastructure. We include several dummies: few banks (if a municipality has less banks than $75 \%$ of the average), very few banks (if a municipality has less banks than $50 \%$ of the average), many banks (if a municipality has more banks than $125 \%$ of the average) andvery many banks (if a municipality has more banks than $150 \%$ of 
the average). In the second estimation we include few and many and in the third estimation very few and very many.

The results are similar to those of the basic model if we take the data from the Packaging Waste Fund. Only for the weight-based system and population density there is a difference: the first is no longer significant and population density is now significant. It should be noted that the data for Packaging Waste Fund are for a smaller time-period (2010-2017) resulting in fewer observations. As Gradus and Dijkgraaf (2019) show the use of the more refined weightbased system increased at the beginning of this century and, due to large administrative costs, has decreased after 2005. However, the result for the bottle bank variable is robust. If we include a dummy for few or many bottle banks (or for very few or very many), we do not even get significant result for bottle banks. Thus, we find no evidence that the effectiveness of increasing the number of bottle banks depend on the density of the existing infrastructure. For other variables the results are similar to the basic model.

Finally, we also investigate several dummies for municipality size (see Table 5). There is some indication for the Netherlands that smaller and rural municipalities recycle more as they have more opportunities to stall containers. However, Dijkgraaf and Gradus (2017) found a positive relation between municipality size and textile recycling. Therefore, we include dummies for small municipalities $(<10,000$ inhabitants), small and medium-sized municipalities $(<10,000$ inhabitants and inhabitants in the range 10,000-15,000), large cities (> 50,000 inhabitants) and very large cities (> 100,000 inhabitants).

From these estimations, we see that for small municipalities with less than 10,000 inhabitants the amount of separate collected glass is 1.5 kilogram (7\%) higher. However, for municipalities with more than 10,000 inhabitants this effect disappears. We have, therefore, indications that the effect of bottle banks might be larger in very small municipalities. For the overall effect in the Netherlands, this is only very marginal as more than $99 \%$ of inhabitants live in municipalities with more than 10,000 inhabitants in 2017.

Overall, our conclusion is that the results are rather robust with respect to effectiveness: increasing the number of bottle banks only imply a small increase in recycling of glass and in several estimations this effect is even not significant from zero. More effective is 
implementing a unit-based pricing system. Nevertheless, such a system can have important disadvantages.

Table 5. Estimation alternative models: size of municipalities

\begin{tabular}{|c|c|c|c|c|}
\hline & $\begin{array}{c}\text { Small } \\
\text { municipalities } \\
\end{array}$ & $\begin{array}{c}\text { Small and medium } \\
\text { municipalities }\end{array}$ & Large cities & $\begin{array}{c}\text { Very large } \\
\text { Cities } \\
\end{array}$ \\
\hline Bottle banks per inhabitant & $0.24 *$ & 0.25 & $0.31 * *$ & $0.30 * *$ \\
\hline Dummy: inhabitants $<10,000$ & $1.55^{* * * *}$ & $1.53 * * *$ & - & - \\
\hline Dummy: inhabitants between $10,000-15,000$ & - & -0.03 & - & - \\
\hline Dummy: inhabitants $>50,000$ & - & - & -0.20 & - \\
\hline Dummy: inhabitants $>100,000$ & - & - & - & -0.42 \\
\hline UBP: volume & 0.41 & 0.41 & 0.42 & 0.42 \\
\hline UBP: frequency & $2.49^{* * * *}$ & $2.49^{* * *}$ & $2.50 * * *$ & $2.51^{* * *}$ \\
\hline UBP: bag & $3.82 * * *$ & $3.82^{* * *}$ & $3.84 * * *$ & $3.83^{* * *}$ \\
\hline UBP: weight & $2.14 * * *$ & $2.14 * * *$ & $2.19 * * *$ & $2.20^{* * *}$ \\
\hline Dummy: low frequency unsorted: $0-12$ & - & - & - & - \\
\hline Dummy: low frequency unsorted: $13-17$ & - & - & - & - \\
\hline Population density & -0.002 & -0.002 & -0.002 & -0.002 \\
\hline Inhabitants/10000 & -0.02 & -0.02 & 0.00 & 0.03 \\
\hline$(\text { Inhabitants/10000) })^{2}$ & -0.001 & -0.001 & -0.001 & -0.001 \\
\hline Household size & -0.77 & -0.78 & -0.53 & -0.63 \\
\hline Income $(€)$ & 0.01 & 0.01 & 0.00 & 0.00 \\
\hline Elderly (\%) & $0.13^{*}$ & $0.13^{*}$ & $0.15^{*}$ & $0.15^{*}$ \\
\hline Ethnicity $(\%)$ & $-0.35 * * *$ & $-0.35 * * *$ & $-0.34 * * *$ & $-0.34 * * *$ \\
\hline Constant & $22.54 * * *$ & $22.55 * * *$ & $22.03 * * *$ & $22.20 * * *$ \\
\hline $\mathrm{R}^{2}$ & 0.81 & 0.81 & 0.81 & 0.81 \\
\hline Observations & 3,647 & 3,647 & 3,647 & 3,647 \\
\hline
\end{tabular}

\section{Cost-effectiveness of increasing bottle banks}

In our dataset, we have 12,473 bottle banks in 2017 . As we have missing data for some municipalities, extrapolating to the number of bottle banks for the Netherlands using the average number of bottle banks per inhabitant results in a total of 16,432 (see Table 6). If the number of bottle banks increases with 800 as requested by ILT the number of bottle banks per 1000 inhabitants increases with 0.05 to 1.10 . From the estimation in Table 2 we can derive that the (separated) glass amount in kilograms per inhabitant will increase with 0.0145 . If we consider the 5\% uncertainty with respect to this parameter estimation, this will be between 0.0004 and 0.0288 . So, on average 800 extra bottle banks means an increase per inhabitants of yearly 21.82 kilograms to 21.83 kilograms, which means an increase in percentages of only $0.06 \%$. 
If we take into account that household or municipal glass waste is about $5 / 6$ of overall glass waste collected and the 800 extra banks have only effect on glass waste collected by municipalities $^{4}$, then the increase in household waste should be $5.6 \%$ to have an increase from $86 \%$ to $90 \%$ in overall target. In such a case, the increase in glass waste per inhabitants should be 1.22 kilogram. Based on the model in equation (1), this means the number of bottle banks per 1000 inhabitants should be 5.27. This means on average 90,000 bottle banks (or the interval 55,000-1.5 million with 95\% certainty). Instead of the number of 800 extra bottle banks this means an increase of 73,500 bottle banks, nearly fivefold the current infrastructure. As we know that the Packaging Waste Fund use 7,000 euro as a proxy for the costs of installing a bottle bank. Therefore, total costs will increase with 515 million euros, but even if we take the lower-bound of the estimated effect of bottle banks on glass collection, this increase will be 270 million euros. Per (metric) ton extra glass waste, costs are on average approximately 24,500 euro, and if we take a lifespan of 15 years, the costs (without operating costs) are approximately 1600 euro. From these figures it is very clear that increasing the number of bottle banks is not cost effective.

\section{Conclusions and discussion}

The Netherlands wants to raise glass recycling from $86 \%$ in 2017 to $90 \%$, while the EU-target is $75 \%$. The inspectorate ILT has ordered that the number of bottle banks should increase with 800 in 2021 and a cost-effectiveness analysis is lacking. Based on the empirical analysis in this paper, there is only an increase of $0.06 \%$ and to achieve this $90 \%$-target the number of bottle banks should increase with 73,500. Most Dutch municipalities have an advanced infrastructure of easily assessable bring locations for glass bottles and we found no evidence that extending this infrastructure will be cost effective.

\footnotetext{
${ }^{4}$ See Afvalfonds $(2016,2018)$. In 2015, total glass waste was 410 kilotons divided between firms 68 (17\%) and households 342 (83\%). In 2017, total glass waste was 430 kilotons, which can be divided between firms 71 $(17 \%)$ and households $379(83 \%)$ compared with a total glass production of 500 kilotons. For $90 \%$ recycling, the extra amount needed is 20 kilotons or $5.6 \%$ of household waste as the extra bottle banks have only effect on the amount collected with the municipal infrastructure.
} 
Table 6. Calculation effectivity extra glass bottle banks

\begin{tabular}{|c|c|c|c|c|c|c|}
\hline $\mathrm{Nr}$ & Contents & Unit & Basis & $+2 \mathrm{SD}$ & $-2 \mathrm{SD}$ & Remark \\
\hline 1 & Glass bottle banks 2017 & 2017 dataset & 12,473 & 12,473 & 12,473 & Measured \\
\hline 2 & +800 & New & 13,273 & 13,273 & 13,273 & Assumption \\
\hline 3 & & Netherlands & 16,432 & 16,432 & 16,432 & Estimated \\
\hline 4 & Inhabitants & 2017 dataset & $12,965,232$ & $12,965,232$ & $12,965,232$ & Measured \\
\hline 5 & & Netherlands & $17,080,000$ & $17,080,000$ & $17,080,000$ & CBS \\
\hline 6 & Glass bottle banks now & Bottle banks per 1000 inhabitants & 1.05 & 1.05 & 1.05 & Measured \\
\hline 7 & +800 & Bottle banks per 1000 inhabitants & 1.10 & 1.10 & 1.10 & $6+800 / 5$ \\
\hline 8 & Effect on glass & kg per inhabitant & 0.01 & 0.03 & 0.00 & From estimation \\
\hline 9 & Glass & kg waste per inhabitant & 21.82 & 21.82 & 21.82 & Measured \\
\hline 10 & $\%$ change & $\%$ & 0.06 & 0.12 & 0.00 & $8 / 9$ \\
\hline 11 & Necessary change & $\%$ waste & 5.6 & 5.6 & 5.6 & Assumption \\
\hline 12 & Necessary change & kg waste per inhabitant & 1.22 & 1.22 & 1.22 & $14 * 9$ \\
\hline 13 & $90 \%$-target & Bottle banks per 1000 inhabitants & 5.27 & 3.22 & 92.57 & From estimation \\
\hline 14 & & Bottle banks & 90,012 & 54,998 & $1,581,096$ & $13 * 5$ \\
\hline 15 & & Extra & 73,580 & 38,566 & $1,564,664$ & $14-3$ \\
\hline 16 & Costs per bottle bank & Euro & 7,000 & 7,000 & 7,000 & Assumption \\
\hline 17 & Extra costs & Million euro & 515 & 270 & 10,953 & $15 * 16$ \\
\hline 18 & & Per ton waste & 24,679 & 12,935 & 524,794 & $17 /(12 * 5)$ \\
\hline
\end{tabular}


Introducing unit-based pricing systems as the bag, weight- and frequency-based system are more effective, as the amounts of separated glass increase substantially. However, these systems can have some adverse effects such as administrative costs and measures needed to avoid illegal dumping. It seems that glass recycling is already on a high-level in the Netherlands and increasing the goal far above the EU-goal seems not effective by increasing bottle banks.

There are many avenues to explore in future research. First, the debate on the impact of unitbased pricing on illegal disposal or waste tourism is still open as data are not readily available. Interestingly, for Switzerland there are two recent opposing indications. Erhardt (2018) investigates whether the introduction of a unit-based garbage fee induces waste dumping in nearby communities which do not implement such a policy and call it a "waste haven effect". Interestingly, he found some evidence for waste havens in a cross-section of 1752 Swiss municipalities. By contrast, in the Swiss city of Lausanne, Carattini et al. (2018) show that four years after the introduction of a unit-based pricing system, illegal disposal remained a minor issue. Therefore, the issue of illegal or illicit dumping of unit-based pricing systems should be studied in more detail. Therefore, we encourage to have more recent and detailed data on illegal dumping is needed. Second, behaviour of the industry and consumers should be studied in terms of prevention of packaging material. In Dijkgraaf and Gradus (2016), we test for plastic packaging the interaction effect of post separation with UBP. As this effect is non-significant and almost zero, this gives an indication that the awareness effect of such a system on reduction of plastic waste through effects of price incentives on buying behaviour is insignificant or very small. As Heller and Vatn (2017) suggest that a price incentive even can become disruptive for certain groups, it is important to study this effect of price incentives further for glass and other packaging material.

\section{References}

Abbot, A., S. Nandeibam and L. O’Shea (2013). Recycling: Social norms and warm-glow revisited, Ecological Economics, 90, 10-18.

Afvalfonds ('Packaging Waste Fund') (2016). Verpakkingen in de circulaire economie: recycling verpakkingen Nederland 2015. Leidschendam: Afvalfonds verpakkingen. 
Afvalfonds ('Packaging Waste Fund') (2018). Verpakkingen in de circulaire economie: recycling verpakkingen Nederland 2017. Leidschendam: Afvalfonds verpakkingen.

Allers, M. and C. Hoeben (2010). Effects of unit-based garbage pricing: a differences-indifferences approach, Environmental and Resource Economics 45:3, 405-428.

Carattini, S., A. Baranzini and R. Lalive (2018). Is Taxing Waste a Waste of Time? Evidence from a Supreme Court Decision. Ecological Economics 148, 131-51.

Dijkgraaf, E. and R. Gradus (2014). Waste management in the Netherlands, in: T. Kinnaman and K. Takeuchi (eds.) Handbook on Waste Management. Cheltenham: Edward Elgar Publishers, 287-315.

Dijkgraaf, E. and R. Gradus (2016). Post Separation of Plastic Waste: Better for the Environment and Lower Collection Costs, Tinbergen Discussion Paper Series 2016103/VI.

Dijkgraaf, E. and R. Gradus (2017). An EU recycling target: what does the Dutch evidence tell us?, Environmental and Resource Economics 68:3, 501-526.

Erhardt, T. (2019). Garbage In and Garbage Out? On Waste Havens in Switzerland. Environmental and Resource Economics 73:1, 251-282.

Eurostat (2019). Waste statistics: statistics explained, Press Release, June 2019.

Gradus, R. and E. Dijkgraaf. (2019). Poorer and less political fragmented Dutch municipalities take tighter waste reduction decisions. Waste Management 88:3, 328-336.

Gradus R., P. Nillesen, E. Dijkgraaf and R. van Koppen (2017). A cost-effectiveness analysis for incineration or recycling of Dutch household plastic waste. Ecological Economics 135, $22-28$.

Gradus, R., G. Homsey, M. Warner and L. Liao (2019). Which US municipalities adopt PayAs-You-Throw and curbside recycling?, Resources, Conservation \& Recycling 143, 178 183.

Heller, M. and A. Vatn (2017). The divisive and disruptive of a weight-based waste fee. Ecological Economics 131, 275-285. 